\title{
Effective public relations programs
}

\section{benefit academic libraries}

By Michael Haeuser

Head Librarian

Gustavus Adolphus College and Evelyn Riché Olivier

Administrative Services Librarian

University of Texas Health Science Center

\section{Academic libraries win a John Cotton Dana Award and}

two Special Awards for outstanding library public relations.

\begin{abstract}
$\mathbf{T}$ his year ALA John Cotton Dana Library Public Relations Awards were given to three academic libraries demonstrating excellence and innovation in a variety of public relations campaigns. The University of Tennessee, Knoxville, Libraries won a John Cotton Dana Award for a year-long public relations program celebrating the opening of its new John C. Hodges Library. The University of Michigan Library won a Special Award for two user awareness campaigns. One introduced MIRLYN, the University's online catalog, and the other publicized Peer Information Counseling (PIC), a library-sponsored minority student support program. New York University Libraries won a Special Award for a unique preservation public relations program raising user and staff awareness of library preservation issues. Each of these winning libraries is recognized by the contest for its creativity and leadership in library administration and management.
\end{abstract}

\section{A golden anniversary}

1989 marks the fiftieth year that the $H$. W. Wilson Company has co-sponsored, with the American Library Association, this prestigious competition. In 1939 ALA's Public Relations Committee and Halsey W. Wilson, president of the company that bears his name, jointly organized the "Library Publicity Honor Roll" and awarded prizes for innovative public relations ideas. Suspended in 1943 for the duration of World War II, it was reconstituted in 1946 as the John Cotton Dana Public Relations Award to honor the career of a librarian who recognized the benefits to library programs that well planned publicity provides.

The contest grants awards in two categories. A John Cotton Dana Award recognizes a library public relations program that is ongoing, sustained and well-rounded. Such a program is directed towards a broad range of existing and potential groups and effectively promotes a complete range of services. A Special Award recognizes a discrete aspect of library public relations program that supports a special project, goal or activity. Special Awards are given for projects that are limited in time, scope, nature or audience.

A record number of academic libraries entered the contest in 1989. Fifteen of the more than 110 entries came from college/university libraries. Of the eight library categories, academic library entries were second only to public library entries.

\section{New library celebrated}

The University of Tennessee, Knoxville, campus 
dedicated its entire publicity program during the academic year of $1987 / 88$ to its new John C. Hodges Library. The John Cotton Dana Award acknowledges the library's role in creating, promoting, and implementing the yearlong celebration. The University of Tennessee, with approximately 25,000 students and 2,000 faculty and staff, is the premier research university of the state. The University has embarked upon a program of excellence designed to attracted distinguished researchers in the sciences, engineering, agriculture, the humanities and social sciences. The new library, costing $\$ 28$ million, is a significant part of that program for excellence.

A number of special events highlighted the Hodges Library celebration, including Library Day 1988, the Southern Writers Program, a series of tours, a library development campaign, and the dedication of the new facility. A central public relations theme was "Writers, Readers, LibrariansPartners in Creativity." The targeted audiences included students, faculty, staff, the UTK administration and the local community.

The success of the UTK Library public relations campaign was measured in several ways. Library statistics such as circulation increased $13.3 \%$, traffic increased by $22.1 \%$, and reference questions increased by $33.5 \%$. Competition for faculty studies and graduate carrels illustrated the achievement of an objective that the library be perceived as the major campus center for scholarly activity. A development program identified as the "Family Campaign" raised more than $\$ 542,600$, which will be used as seed money for a major development campaign to raise endowments for the Library collections.

The John C. Hodges Library Open House and Dedication ceremonies were attended by more than 700 people. The Southern Writers Program was well received with more than 300 people at each of seven readings by writers George Garrett, Alex Haley, Al Young, Wilma Dykeman, Lee Smith, Bobbie Ann Mason, and Donald Justice. Library Day 1988 was also a success with approximately 200 librarians from the state and region and 400 others present for the principal lecture by Lamar Alexander, new president of the University of Tennessee and former governor.

The involvement of the Panhellenic Council in fundraising and acting as volunteer tour guides was noted as unusual and instrumental in making the celebration a community effort. A library logo featuring the new building was used to create a uniform and attractive design element for all library publications. The Hodges Library image was also used on all campus publications throughout the year, reinforcing the library as a place for creative endeavor, for research, for serious searching for information and the place to be on the UTK campus.

\section{Michigan's MIRLYN}

A Special Award was given to the University of Michigan Library for two outstanding user awareness campaigns. The first introduced MIRLYN, the university's online catalog, in a nonthreatening manner while emphasizing its exciting possibilities. The second campaign publicized Peer Information Counseling (PIC), a minority student

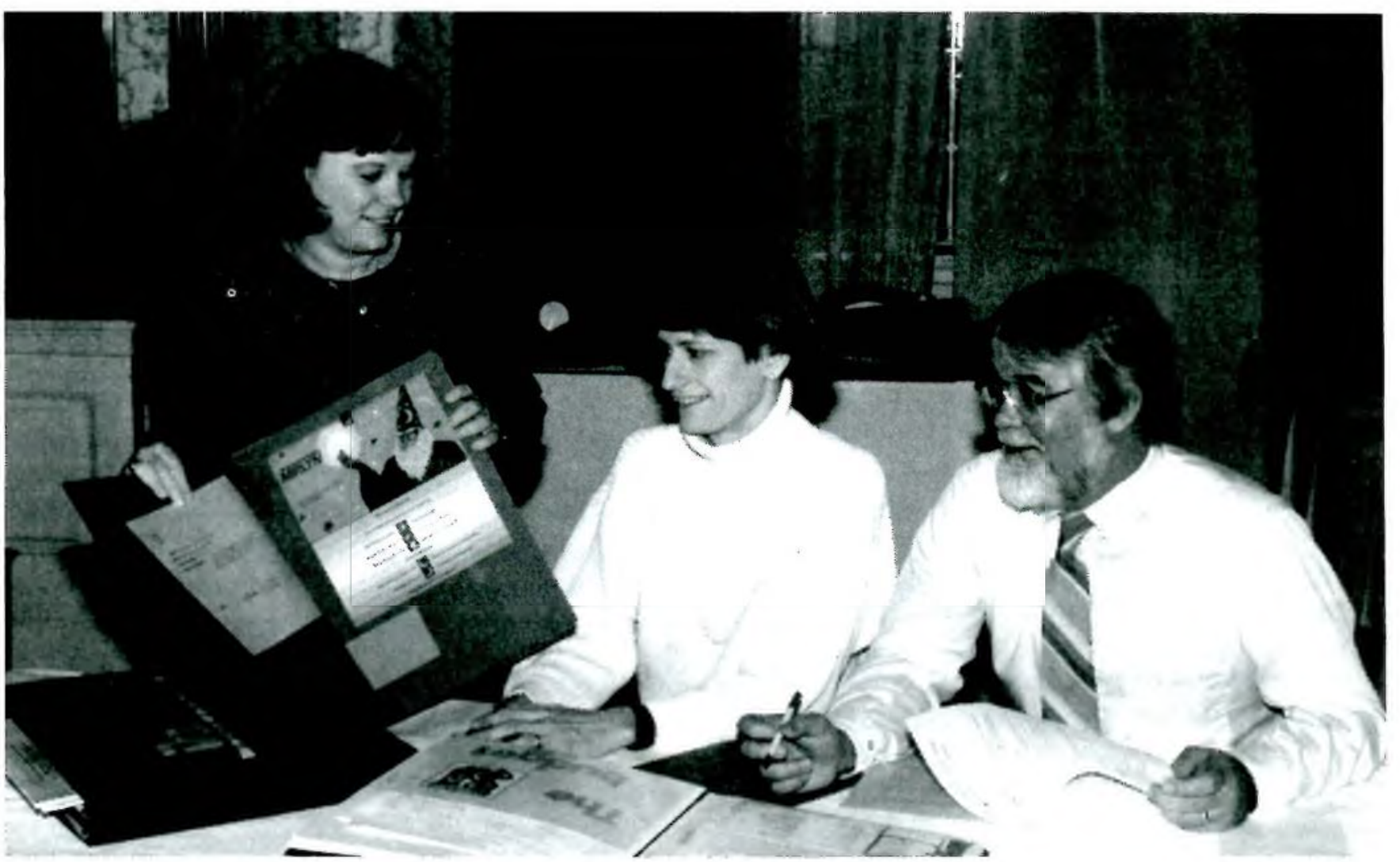

John Cotton Dana Award judges (left to right): Evelyn Olivier (University of Texas Health Science Center), Pyddney K. Jones (Bluegrass S. Regional Library Office), and Michael Haeuser (Gustavus Adolphus College). 
support program affording the opportunity for minority undergraduates to serve as reference assistants. The University of Michigan, located in Ann Arbor has more than 49,000 students and serves a population of some 75,000. The University of Michigan Library is composed of 21 libraries including the Undergraduate Library, which was responsible for the PIC program.

The public relations campaign for MIRLYNthe Michigan Research Library Network-had both internal and external functions. Internal promotion focused on keeping the staff up-to-date and reinforcing morale. At each staff session attendees received promotional giveaways such as pens, pencils, cups, kazoos, notepads, frisbees, and other novelties. External public relations updated administrators, teaching faculty and primary researchers through newsletters and other publications. Posters and book bags were distributed across campus and quick guides and flip-chart manuals were placed at all public terminals. A "mirlyninfo" helpline was added to the campus email system. A ribbon-cutting ceremony and reception officially dedicated MIRLYN on September 20,1988 .

Central to the user awareness campaign was the use of the wizard image and the theme, "The Magic of MIRLYN." Merlin made his first public appearance on posters and guides and continues to appear on ads and bulletin boards. The public relations program was primarily targeted to University of Michigan students, faculty and staff, with additional publicity to the surrounding community.

The goals of the campaign were to develop an identity for MIRLYN as an online catalog, to educate the public to MIRLYN's capabilities as an integrated library system, to alleviate concerns over the change from a card catalog to an online catalog, and to create a sense of excitement about MIRLYN, without undermining the serious, scholarly nature of the project. Specific objectives such as achieving near $100 \%$ name recognition and encouraging participation at public training sessions were also identified. The successful accomplishment of these goals and objectives was measured by very positive user response, by the strong popularity of MIRLYN publications and training sessions and by the excellent press coverage in both the local media and professional library publications.

The internal public relations, spearheaded by the MIRLYN Implementation Team, were innovative, original, and effective. As a result, the startup of MIRLYN was smooth and orderly. The staff was well-trained and prepared and the public was properly informed. Best of all the staff perceived this project as both fun and exciting. Of special note was the graphic design of the poster and user guide. The artwork, colors, and layout seemed to capture an aura of mystery and power without trivializing or misrepresenting the system. Most importantly the campaign succeded in making the name MIRLYN synonymous with the online catalog.

\section{Peer Information Counselors}

The University of Michigan Undergraduate Library was responsible for a user awareness program for Peer Information Counselors (PIC) who serve at the Reference Desk alongside professional librarians. These minority student counselors answer basic questions, provide one-on-one assistance, and offer tutoring sessions on word processing. Although PIC was established in 1985, too few of the University's 35,000 undergraduates knew about PIC services.

The first campaign activity was to develop a logo for PIC and to devise the theme- "Information is our middle name." The logo and theme appeared on brochures, posters and ads. Brochures were passed out at the reference desk, and were mailed out to each minority student. Posters were distributed across campus and a 24-hour hotline, "PICLine," was established to allow students to make appointments at their own convenience. The student newspaper and campus buses carried PIC ads. The PIC students developed their own newsletter which was distributed twice yearly to each minority undergraduate.

The goals of the PIC program were to increase PIC's presence among the target audience; to increase PIC's visibility throughout the campus population, contributing to the university's goal of diversity; to develop the image of PIC counselors as accessible, helpful and knowledgeable; and to develop PIC's image as a vital link to information literacy. Specific public relations objectives included the personal contact of each first-year minority student, the achievement of $100 \%$ name recognition among minority students, a substantial increase in the use of PIC-Line, and a substantial increase in the number of word processing tutorials.

The PIC public relations campaign received favorable response, and for the most part achieved name recognition among minority undergraduates. The feedback from press coverage and advertising was substantially improved and the PICLine usage increased. The PIC Newsletter that utilized desktop publishing was especially effective in communicating the value of word processing tutorials. Tutorial appointments increased by $30 \%$. Overall, there was a positive shift among library users with non-minority students approaching the PIC staff at the reference desk regularly. The PIC program has benefited the library as a whole by publicizing minority Peer Information Counselors as intelligent, valuable assistants.

\section{"Handle with Care"}

The New York University Libraries have received a Special Award for their public relations campaign on preservation. The program, designed to raise awareness and educate users about various preservation issues, included: bookmarks; a videotape, entitled "Handle with Care"; a specially de- 
signed plastic book bag; a preservation exhibit called "Enemies of Books"; and a Disaster Plan Workbook. The New York University Libraries serve approximately 50,000 campus users as well as the New York metropolitan community. The preservation campaign was targeted at the university community and non-NYU students who use the Bobst Library through library consortia arrangements. The Bobst Library and Study Center houses two-thirds of the library's 3 million volumes.

One of the creative aspects of the preservation campaign was the use of BobCat, the friendly, furry cat who has come to symbolize the library's online catalog (Bobst Catalog). BobCat was depicted on the preservation book bags, splashing through the rain and happily protected by his umbrella. The implication is clear that BobCat is happier when kept dry, and so are library books. The bookmarks incorporate the motif of the library's marble floor, a pattern familiar to library users. In addition to preservation information, the bookmarks also publicize library photocopiers, list library hours and phone numbers, and identify materials location codes. Some 1,000 book bags and 12,000 bookmarks have been distributed.

The "Handle with Care" video produced by the NYU film students and faculty is especially effective. The tape is run on a continuous loop at a kiosk at the library's entrance and is shown periodically throughout the semester. It is short and humorous, thus encouraging spontaneous viewing. In "Handle with Care" a likable but careless young man demonstrates all the ways to mistreat a book, including dunking it in the bathtub and mishandling it at the copier. A satiric off-screen narrator comments on the proper way to handle books. In addition to NYU footage, fifty copies of the video have been sold to other libraries.

The preservation exhibit, "Enemies of Books," illustrates the history of papermaking, preservation techniques, and book handling-both proper and improper. The exhibit, originally slated for a one-month run, was extended to six months. The final preservation item, NYU's Disaster Plan Workbook, is geared to the library community and includes information on emergency procedures, computers and resources. It also allows space for individual institutions to fill in local details such as emergency phone numbers and supplies. Almost 1,300 workbooks have been sold across the country since 1984.

\section{More ideas}

In addition to the three winning libraries, four other academic library entries reached the final round of judging. One clever idea was the promotion of a term paper counseling project utilizing "Publisher's Clearinghouse Sweepstakes-like" mailings targeted to a specific faculty. Another library promoted library instructional programs at remote extended campus sites. The Smithsonian
Institute exhibit, "Field to Factory," which concerns Afro-American migration, was the focus of another academic library public relations program. One entry went so far as to host Queen Sylvia of Sweden at the dedication of their new library.

These entries and others will be highlighted in the ALA publication, Great Library Promotion Ideas, 6 th ed., to be issued later this year. The winning entries will also be on display at the John Cotton Dana booth at ALA Annual Conference in Dallas.

\section{Considerations for 1990}

This year's winners share a common theme. Though not unique, each entry showed evidence on setting realistic goals accomplished by effective public relations activities. For an article by Jon Eldredge describing the key ingredients of a winner, see C $\} R L$ News, October 1986, pp. 577-82. Last year's winners were identified in $C \& R L$ News, July/August 1988, pp. 419-22. Entry packets for the 1990 contest are available from the Marketing Department, H. W. Wilson Company, 950 University Avenue, Bronx, NY 10452.

Take a chance and show other libraries the effectiveness of your public relations program.

\section{More Dallas programs}

On Sunday, June 25, 9:00-11:00 a.m., the ULS Current Topics Discussion Group will present "Serving Secondary Clientele: Beyond the Ivory Tower," a program that will focus on the needs and demands of external library users and the ways libraries have responded to the challenge of this new clientele. Jay Poole, assistant university librarian for public services at the University of California, Irvine, will speak on "The Gain, The Pain: Initiating Services for Secondary Users," with particular focus on the efforts to establish public library services on the UC-Irvine campus. Helen Josephine, information manager of FIRST at Arizona State University, will cover "New Clientele, New Service Needs: Academic Libraries' Fee-Based Information Centers." She will highlight some of the interesting legal issues that arose when ASU's fee-based information service was challenged by a private information broker. The area of "Remote Access to Online Catalogs/Databases by Secondary Users" will be addressed by John Abbott, head of the Natural Resources Library at North Carolina State University.

The ALA Association of Specialized and Cooperative Library Agencies' Decade of Disabled Persons Committee is sponsoring a program in Dallas on Sunday, June 25, 2:00-4:00 p.m., entitled, “A Job for Every Person: Creative Options for Em- 
ploying Persons with Disabilities.” The speaker will be Debbie Buckingham of the Dallas Rehabilitation Institute. She will address the issue of adap- tations that can be made in library settings when employing people with disabilities.

\section{ALA report calls for "information literate" society}

The American Library Association has made available the final report of the ALA Presidential Committee on Information Literacy, which calls for education reforms and new roles for libraries in advocating the importance of information literacy to an informed citizenry and successful business.

Chaired by Patricia Senn Breivik, director of the Auraria Library at the University of Colorado at Denver, the Presidential Committee was appointed in 1987 by ALA President Margaret Chisholm. Its goal was to define information literacy within the higher literacy skills and its importance to student performance, life-long learning and active citizenship.

ALA President William Summers spoke of the growing crisis in information literacy at the ALA Midwinter Meeting in Washington: "Today's information and technology abundance has made most people dependent on others to access and reduce information to manageable segments. Prepackaged information from our schools and news media have conditioned people to accept the opinions of others without much thought.... Information literate people are those who have learned how to learn. They know how to learn because they know how knowledge is organized, how to find information and how to use information in such a way that others can learn from them."

The report proposes restructuring the learning process away from textbooks, workbooks and lectures to a learning process based on the information resources that will be available for learning and problem-solving throughout people's lifetimes. This information age school would be more interactive, with teachers working consistently with librarians, media resource people, and instructional designers.

The report recommends specifically that:

1. Librarians and others reconsider the ways information is organized, accessed and defined.

2. ALA lead the formation of a National Coalition on Information Literacy in concert with other national organizations and agencies to promote information literacy.

3. Research and demonstration projects be undertaken.

4. State departments of education, commissions on higher education and academic governing boards ensure that a climate conducive to students' becoming information literate exists in their states and on their campuses.

5 . Teacher education and performance requirements change so that teachers become facilitators of student learning, rather than presenters of ready-made information.

6. Information literacy is made a top agenda item for the next White House Conference on $\mathrm{Li}$ brary and Information Services.

The following organizations (listed here with their representatives) have agreed to be founding members of the National Coalition on Information Literacy: American Association of Colleges for Teacher Education (David Imig), American Association of School Administrators (Richard D. Miller), American Library Association (Patricia Senn Breivik), Council of Chief State School Officers (Gordon M. Ambach), Council of Independent Colleges (Allan P. Splete), Education Commission of the States (Rexford Brown), Mastery in Education Project of the National Education Association (Robert M. McClure), National Commission on Libraries and Information Science (Susan K. Martin), and the U.S. Office of Educational Research and Improvement (Anne Mathews).

Gordon Ambach will speak on information literacy as part of William Summers's presidential program in Dallas, Sunday, June 25, 2:00-5:00 p.m.

Single copies of the committee's Information Literacy report may be requested from the ALA Public Information Office, 50 E. Huron St., Chicago, IL 60611.

\section{Quick comeback from fire}

Western Carolina University's Hunter Library, Cullowhee, North Carolina, was fully operational just eight weeks after a fire which destroyed the Media Center and caused extensive soot damage to the reference, serials and documents collection. Estimates of the damage exceed $\$ 1$ million.

April 24 marked the HOT (Hunter Opens Today) Celebration which honored the local fire departments, the M.F. Bank Restoration Company of Atlanta, Ga., the library faculty and staff, and Director William J. Kirwan. Accompanied by musical flourishes, University Chancellor Myron L. Coulter cut the fire line ribbon and invited celebrants to be grateful that the heart of the university was restored.

"Infiremation" exhibits featuring soot silhouettes, a melted clock and phone, and various charred items proved to be popular with patrons sporting buttons that read, "Smile, You have a library!" 


\section{The professional's choice for}

\section{reliable business data.}

\section{Ward's Business Directory of U.S. Private and Public Companies 1989}

I

n the new 1989 Ward's, you'll find complete information on approximately 90,000 businesses - over $90 \%$ of which are privately held!

\section{Confirmed Statistics}

Ward's gives you information on the companies that count: from the smaller private firms to the largest publicly held companies. And, Ward's is the only place you'll find a $100 \%$ private company verification rate-data listed in Ward's is verified through direct company contact!

\section{Three Volumes of Specialized Data}

- Vol. 1 lists companies with over $\$ 11.5$ million in sales, in alphabetic and geographic state and zip code sections.

- Vol. 2 lists private and public companies with $\$ .5$ to $\$ 11.5$ million in sales, again in alphabetic and geographic state and zip code sections.

- Vol. 3 lists private and public companies ranked by sales within a particular industry and shows corporate linkage.

\section{Entries Provide the Entire Picture}

Single-line listings for each company include:

- company name, address, phone

- names of chief executives

- 4-digit SIC codes (1987 revised) with descriptions

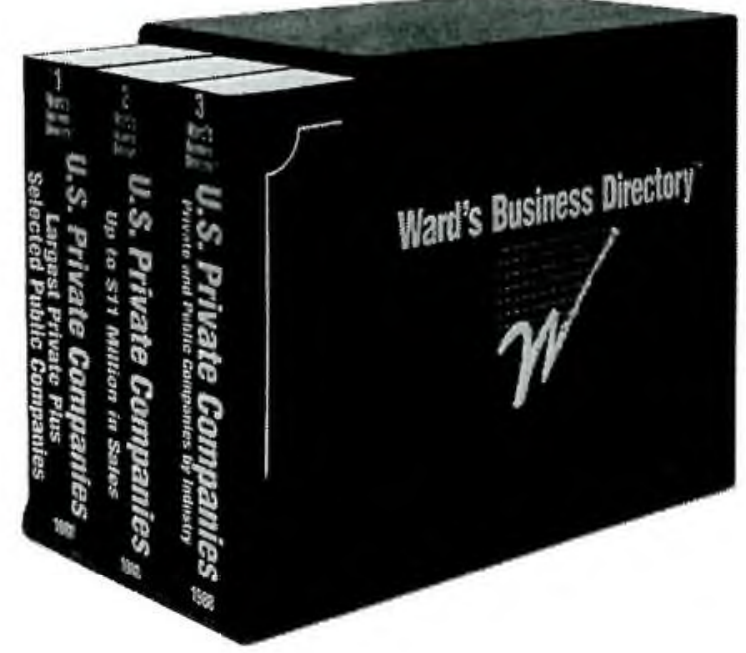

- sales figures

- number of employees

- import/export designation

- public/private, subsidiary/division designations

- year founded

If you'd like to order by phone or you need more information, call us toll-free (from anywhere in the U.S. and Canada) at 1-800-223-GALE.

Ward's Business Directory of U.S. Private and Public Companies 1989, 3 volume set with slipcase, Order \#30123-99961, \$845.00.

Vol. 1, Over \$11.5 Million in Sales, Order \#30124$99961 \$ 395.00$.

Vol. 2, From \$.5 to \$11.5 Million in Sales, Order \#30125-99961, \$395.00.

Vol. 3, Ranked by Sales Within Industry, Order \#30126-99961, \$595.00.

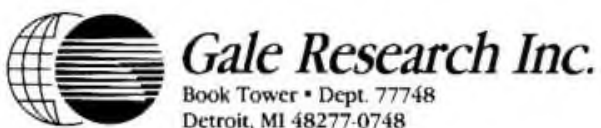

